\title{
Determinants of Bone Health in Older Adults
}

\section{Geriyatrik Bireylerde Kemik Sağlığının Belirteçleri}

\author{
Esma Nur KOLBASI ๑, Filiz DEMIRDAG ๑, Kubra YILDIZ ๑, Sadiye MURAT ๑, Gozde BALKAYA ๑
}

Ethics Committee Approval: This study was approved by the Istanbul Medeniyet University Goztepe Training and Research Hospital, Clinical Studies Ethics Committee, 12 December 2018, 2018/0478.

Conflict of interest: The authors declare that they have no conflict of interest.

Funding: None.

Informed Consent: Informed consent was taken from the patients enrolled in this study.
Cite as: Kolbasi EN, Demirdag F, Yildiz K, Murat S, Balkaya G. Determinants of bone health in older adults. Medeniyet Med J. 2020;35:23-8.

\begin{abstract}
Objective: The objective of this study was to determine the predictors of bone health in older adults.

Methods: A total of 313 subjects older than 65 years (mean age $74.2 \pm 6.4$ years, $70.6 \%$ female) were included in the study. Demographic characteristics of participants such as gait speed, handgrip strength, level of physical activity (using Rapid Assessment of Physical Activity-RAPA scale), vitamin D levels, $T$ scores of femur neck (FN) and lumbar spine (LS) were recorded. Results: Based on FN, $40.7 \%$ of participants had normal $T$ scores whereas $46.2 \%$ and $13.1 \%$ of them were osteopenic and osteoporotic, respectively. FN was correlated with age (r:-0.184, $p<0.001), B M I(r: 0.269, p<0.001)$, and handgrip strength (r:0.149, p:0.009) in addition to the aerobic subscale of RAPA (RAPA-aerobic) (r:-0.133, p:0.02). Similarly, the LS was correlated with female gender $(r: 0.207, p<0.001)$, age $(r: 0.136, p: 0.016)$, body mass index $(B M I)(r: 0.246$, $p<0.001)$ and handgrip strength $(r: 0.217, p<0.001)$. The predictors of bone health were decided upon using multiple logistic regression analysis. The deterministic model consisted of age, gender, BMI, height, weight, handgrip strength, gait speed, RAPA-aerobic and vitamin D. For LS dependent variable, the overall model was significant (F:10.149, $p<0.001)$. However, only two variables were significant predictors in the model ie. weight $(\beta: 0.389, p<0.001)$ and handgrip strength ( $\beta=0.186, p<0.001)$. Similarly for independent variable of $F N$, the overall model was significant (F:6.525, $p<0.001$ ) and only two variables were significant predictors: weight ( $\beta: 0.371$, $p<0.001)$ and RAPA-Aerobic ( $\beta: 0.148, p: 0.009)$.

Conclusion: Lower levels of body weight, participation in aerobic activity and handgrip strength might be risk factors for deterioration of bone health in older adults.
\end{abstract}

Keywords: Osteoporosis, physical activity, elderly

öz

Amaç: Bu çalışmada amaç, yaşıı bireylerde kemik sağlığını belirleyen faktörleri saptamaktır. Metod: 65 yaş ve üzeri 313 birey (ort. yaș $74.2 \pm 6.4$ yll, \%70.6 kadın) çalıșmaya dahil edildi. Demografik veriler, yürüyüs hızı, kavrama kuvveti, fiziksel aktivite düzeyi (Fiziksel Etkinliğin Hızlı Değerlendirilmesi- FEHD kullanılarak) ve vitamin D seviyeleri, femur boyun (FN) ve lumbal omurgaya (LS) ait T skorları kaydedildi.

Bulgular: FN'e göre katılımclların \%40,7'si normal T skoru düzeylerine sahipken; \%46,2'si osteopenik ve \%13, 1'i osteoporotikti. FN, yaş (r:-0.184, p<0.001), VKi (r:0.269, $p<0.001)$ ve kavrama kuvvetine (r:0.149, p:0.009) ek olarak FEHD'nin aerobik alt skalası (FEHD-aerobik) (r:-0.133, $p: 0.02)$ ile ilișkiliydi. Benzer șekilde $L S$, kadın cinsiyet (r:-0.207, $p<0.001)$, yas (r:0.136, $p: 0.016)$, vücut kitle indeksi (VKi) (r:0.246, $p<0.001)$ ve kavrama kuvveti (r:0.217, $p<0.001)$ ile ilişkiliydi. Kemik sağlığının belirleyicileri çoklu lojistik regresyon analizi kullanılarak kararlaştırıldı. Belirleyici model içerisinde yaş, cinsiyet, VKi, boy, kilo, kavrama kuvveti, yürüyüş hızı, FEHD-aerobik ve vitamin D yer aldı. LS bağımsız değişkeni için, model anlamlıydı (F:10.149, p<0.001); ancak, modelde yer alan değisskenlerden yalnızca kilo $(\beta: 0.389, p<0.001)$ ve kavrama kuvveti $(\beta: 0.186$, $p<0.001)$ anlamlı belirleyiciydi. Benzer şekilde FN bağımsız değişkeni için, model anlamlıydı (F:6.525, $p<0.001)$ ve yalnızca iki değişken anlamlı belirleyiciydi: kilo $(\beta: 0.371, p<0.001)$ ve FEHD-aerobik ( $\beta: 0.148, p: 0.009$ ).

Sonuç: Düşük vücut ağırlı̆̆ı, aerobik aktivite katılım düzeyi ve kavrama kuvveti gibi faktörler yaşlı bireylerde kemik sağlığının bozulması açısından risk faktörü olabilir.

Anahtar kelimeler: Osteoporoz, fiziksel aktivite, yaşıı
Received: 18 November 2019

Accepted: 6 February 2020

Online First: 28 February 2020

Corresponding Author:

E.N. Kolbasi

ORCID: 0000-0002-5058-2374

Istanbul Medeniyet University,

Department of Physiotherapy and Rehabilitation, Istanbul - Turkey

esmanur.kolbasi@medeniyet.edu.tr

\section{F. Demirdag}

ORCID: 0000-0002-5751-936X

G. Balkaya

ORCID: 0000-0001-9397-4733

Istanbul Medeniyet University Göztepe Training and Research Hospital, Department of Internal Medicine, Istanbul, Turkey

K. Yildiz

ORCID: 0000-0002-4485-6244 Istanbul Medeniyet University, Department of Nutrition and Dietetics, Istanbul, Turkey

S. Murat

ORCID: 0000-0002-6544-7095

Istanbul Medeniyet University Göztepe Training and Research Hospital, Department of Physical Medicine and Rehabilitation, Istanbul, Turkey

This study has been presented in $2^{\text {nd }}$ International Conference on Life and Engineering Sciences held in 27-29 June 2019, Istanbul, Turkey 


\section{INTRODUCTION}

As a result of aging process, the structure, composition and function of bone tissue deteriorates, which in turn leads to osteoporosis ${ }^{1}$. Osteoporosis is an insidious disease that causes several secondary problems. Among these secondary problems, falls and frailty fractures are the most common ones $^{2}$. Unfortunately, this chain of problems (i.e. poor bone health, falls and fractures) may cause life-threatening conditions for older adults. Therefore, it is highly important to determine the predictors of bone health in geriatric population.

In the current literature, there are a lot of factors found to be associated with poor bone health such as body mass index (BMI) ${ }^{3}$, low vitamin-D status $^{4}$, low levels of physical activity and handgrip strength $^{5}$, etc. Yet, none of them is established as a definite predictor because of the conflicting evidences. The studies investigated limited numbers or only one of the predictors at a time rather than multiple predictors or combining effects of multiple predictors, which made it hard to estimate the true predictors of bone health. Thus, this study aims to determine the predictors of bone health in older adults by investigating many possible predictors.

\section{MATERIAL and METHODS}

The study protocol was approved by the ethics committee and all participants gave written informed consent before data collection began. The patients who consulted to the geriatric outpatient clinic between December 2018 and June 2019 were included in the study. The inclusion criteria were: a) being at or over the age of 65, b) being able to perform Mini-Mental State Examination (MMSE) and get 24 points or higher score, c) being able to complete 6-meter walk test (6mwt) d) not actively receiving a treatment for osteoporosis.

Initially, a demographic form inquiring the infor- mation about age, sex, comorbidities, weight, height, BMI etc. was filled out by the participants. Secondly, the handgrip strength was measured by using Takei $^{\odot}$ Hand-held Dynamometer (Takei Scientific Instruments Co., Ltd, Tokyo, Japan) with the patient seated and arms extended on each side. The procedure was performed 3 times with both arms. The highest score was recorded for handgrip strength ${ }^{6}$. 6mWT was performed to obtain the gait speed of the patients based on the original test protocol ${ }^{7}$.

Afterwards, the participation level to aerobic, strength and flexibility activities was assessed with Rapid Assessment of Physical Activity (RAPA) ${ }^{8}$. Vitamin-D levels were obtained by blood test. Lastly, dual energy x-ray absorptiometry (DEXA) scanner was used to measure the health status of the bones. Based on the T scores calculated from femur neck (FN) and lumbar spine (LS), subjects divided into 3 groups as follows: a) normal: $\mathrm{T}$ score $>-1.5, \mathrm{~b})$ osteopenic: $\mathrm{T}$ score $>-2.5$ and $<$ -1.5, c) osteoporotic: T score $<-2.5^{9}$.

Package for Social Science (IBM SPSS Statistics, New York, USA) version 25.0 was used to perform statistical analyses. Since the data exhibited non-normal distributions, Spearman's correlation tests were performed. The predictors of bone health were analyzed by multiple linear logistic regression analysis. The statistical level of significance was set at $\mathrm{p}<0,05$.

\section{RESULTS}

In total, 313 older adults (mean age $74.17 \pm 6.4$ years, $70.6 \%$ female) were included in the study. Table 1 indicates the demographic and clinical characteristics of the participants.

Possible correlations between FN/LS and several factors such as age, gender, gait speed etc. were investigated. The results of correlation analysis are shown in Table 2. 
Table 1. The demographic and clinical characteristics of patients.

\begin{tabular}{|c|c|c|c|}
\hline Variables and Tests & $\begin{array}{l}\text { Patients } \\
\text { (n:313) Mean. } \pm \text { SD }\end{array}$ & Variables and Tests & $\begin{array}{l}\text { Patients } \\
(\mathrm{n}: 313) \text { Mean. } \pm \text { SD }\end{array}$ \\
\hline Age (years) & $74.2 \pm 6.4$ & $\mathbf{F N}$ & \\
\hline Gender (f/m) & $70.6 / 29.4$ & Normal (\%) & 40.7 \\
\hline Weight (kg) & $70.7 \pm 13.4$ & Osteopenic(\%) & 46.2 \\
\hline Height (cm) & $157.3 \pm 9.3$ & Osteoporotic (\%) & 13.1 \\
\hline BMI $\left(\mathrm{kg} / \mathrm{m}^{2}\right)$ & $25.7 \pm 9.6$ & LS & \\
\hline Vitamin-D (ng/mL) & $23.3 \pm 17.9$ & Normal (\%) & 41.7 \\
\hline Gait speed $(\mathrm{m} / \mathrm{s})$ & $0.9 \pm 0.45$ & Osteopenic(\%) & 44.7 \\
\hline Handgrip strength (kg) & $22.3 \pm 8.8$ & Osteoporotic (\%) & 13.6 \\
\hline RAPA-Aerobic & & RAPA-Strength\&Flexibility & \\
\hline Sedentary (\%) & 3.8 & None $(\%)$ & 85.9 \\
\hline Underactive (\%) & 2.6 & Strength (\%) & 3.2 \\
\hline Regular underactive-Light Activities (\%) & 27.9 & Flexibility (\%) & 7.1 \\
\hline Regular underactive (\%) & 37.2 & Both $(\%)$ & 3.8 \\
\hline Regular Active (\%) & 28.5 & & \\
\hline
\end{tabular}

BMI: Body-Mass Index; RAPA: Rapid Assessment of Physical Activity; DEXA-FN: T score of the femur neck in dual energy x-ray absorptiometry; DEXA-LS: T score of the lumbar spine in dual energy x-ray absorptiometry.

Table 2. The results of correlation analysis.

\begin{tabular}{|c|c|c|}
\hline Correlations & $\begin{array}{l}\text { LS } \\
\text { r;p }\end{array}$ & $\begin{array}{l}\text { FN } \\
\mathbf{r} ; \mathbf{p}\end{array}$ \\
\hline $\begin{array}{l}\text { Gender (Female) } \\
\text { Age } \\
\text { Weight } \\
\text { Height } \\
\text { BMI } \\
\text { Vitamin-D } \\
\text { Handgrip strength } \\
\text { Gait speed } \\
\text { RAPA-Aerobic }\end{array}$ & 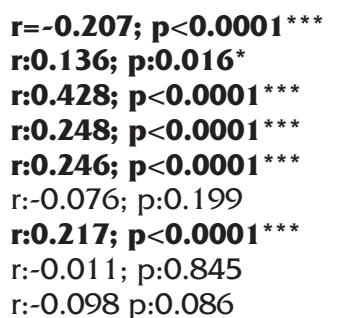 & $\begin{array}{l}\text { r:-1.72; } \mathbf{p}: 0.078 \\
\text { r:-0.184; } \mathbf{p}<0.001^{* *} \\
\text { r:0.368; } \mathbf{p}<0.0001^{* * *} \\
\text { r:0.126; } \mathbf{p}: 0.028^{*} \\
\text { r:0.269; }<<0.0001^{* * *} \\
\text { r:0.29;p:0.631 } \\
\text { r:0.149; }: 0.009^{* *} \\
\text { r:0.078; }: 0.184 \\
\text { r:-0.133; }: 0.02^{*}\end{array}$ \\
\hline
\end{tabular}

Bold numbers show significant results. *Significant, ${ }^{* *}$ Highly significant, ${ }^{* * *}$ Very highly significant. BMI: Body-Mass Index; RAPA: Rapid Assessment of Physical Activity; DEXA-FN: T score of the femur neck in dual energy X-ray absorptiometry; DEXA-LS: T score of the lumbar spine in dual energy $x$-ray absorptiometry.

Table 3. The results of regression analysis for LS.

\begin{tabular}{llll}
\hline Predictor & F & $\beta$ & p \\
\hline Model & 10.149 & & $<\mathbf{0 . 0 0 1} 1^{* *}$ \\
Vitamin-D & & -.017 & 0.747 \\
Age & & 0.007 & 0.89 \\
RAPA-Aerobic & 0.099 & 0.084 \\
BMI & 0.006 & 0.918 \\
Weight & 0.391 & $<\mathbf{0 . 0 0 1} 1^{* *}$ \\
Height & -0.010 & 0.85 \\
Handgrip strength & & 0.175 & $\mathbf{0 . 0 0 3}$ \\
Gait speed & & -0.076 & 0.172 \\
\end{tabular}

Bold numbers show significant results. *Significant, **Highly significant, ${ }^{* * *}$ Very highly significant. BMI: Body-Mass Index; RAPA: Rapid Assessment of Physical Activity; DEXA-LS: T score of the lumbar spine in dual energy $x$-ray.
Table 4. The results of regression analysis for $F N$.

\begin{tabular}{llll}
\hline Predictor & F & $\beta$ & P \\
\hline Model & 6.525 & & $<\mathbf{0 . 0 0 1} \mathbf{1}^{* *}$ \\
Vitamin-D & & 0.06 & 0.289 \\
Age & -0.04 & 0.479 \\
RAPA-Aerobic & 0.134 & $\mathbf{0 . 0 2 6}$ \\
BMI & -0.006 & 0.925 \\
Weight & 0.366 & $<\mathbf{0 . 0 0 1} \mathbf{1}^{* *}$ \\
Height & -0.005 & 0.931 \\
Handgrip strength & 0.043 & 0.495 \\
Gait speed & 0.04 & 0.06
\end{tabular}

Bold numbers show significant results. *Significant, ${ }^{* *}$ Highly significant, ***Very highly significant. BMI: Body-Mass Index; RAPA: Rapid Assessment of Physical Activity; DEXA-FN: $T$ score of the femur neck in dual energy $x$-ray absorptiometry. 
After the correlation analyses, multiple regression analyses were performed in order to determine predictors of FN and LS. The predictor model consisted of vitamin D, age, RAPA-aerobic, BMI, weight, height, handgrip strength and gait speed. The results of regression analysis are shown in Tables 3 and 4 .

For LS dependent variable, the overall model was significant (F:10.149, $\mathrm{p}<0.001$ ). However, only two variables were significant predictors in the model including weight $(\beta: 0.389, p<0.001)$ and handgrip strength $(\beta: 0.186, p<0.001)$.

Similarly, for FN dependent variable, the overall model was significant ( $\mathrm{F}: 6.525, \mathrm{p}<0.001)$ and only two variables were significant predictors including weight $(\beta: 0.371, p<0.001)$ and RAPA-Aerobic ( $\beta: 0.148, p: 0.009)$.

\section{DISCUSSION}

Our findings suggest that among several possible factors, only lower body weight may be associated with worse bone health in both LS and FN in older adults. In addition, the participation level to aerobic activities may be a determinant for FN, but interestingly not for LS. On the contrary, handgrip strength of older adults may be a predictor for bone health in LS, but not for FN.

Similar to our study, Gunn et al. ${ }^{10}$ stated that bone health was positively associated with body weight in postmenopausal women. The authors also underlined the importance of maintaining adequate body weight in terms of reducing bone loss. The rationale of this notion has been broadly explained by Reid in $2010^{11}$. According to Reid ${ }^{11}$, fat and bone tissues are linked by numerous pathways, which allow bone structure to serve as a skeleton to the adipose tissue. Therefore, obesity is protective against osteoporosis. On the other hand, there are studies stating that higher BMI is an opposing predictor of bone mineral density 3,12 since the pro-inflammatory cytokines released by the adipose tissue affect osteoclastic and osteoblastic activity, which in turn leads to formation of lower bone mineral density ${ }^{12}$.

Our results were consistent with the literature regarding relationship between physical activity and bone health ${ }^{13-15}$. In a recent meta-analysis ${ }^{16}$, an inverse association was found between physical activity and overall fracture risk. This finding indicates that increased physical activity leads to an increased bone mineral density and eventually the fracture risk is reduced ${ }^{17,18}$. Nonetheless, our findings suggest a site-specific effect (i.e. physical activity level is a predictor of FN, but not LS). We believe that this effect might be originated from the difference between the influences of current participation to physical activity and participation at the time of bone mass development required for bone health. According to an earlier study ${ }^{19}$, LS was associated with regular physical activity participation in advanced age whereas FN was associated with current level of physical activity. Considering the earlier findings and the fact that our study only focused on current level of physical activity, our site-specific results are reasonable and in line with the literature.

The site-specific predictor value of handgrip strength for bone health is a controversial topic. There are few studies suggesting that handgrip strength is a predictor for $\mathrm{LS}^{20}$, but not for $\mathrm{FN}^{20,21}$ or for both ${ }^{22}$. Considering the fact that grip strength is a marker of overall fragility and physical health condition in elderly ${ }^{23,24}$ in addition to the findings from current literature, it is obvious that the results of the present study cannot be interpreted in a sense that handgrip strength is definitely not a predictor of FN. Therefore, this topic remains unclear and to clarify the association between handgrip strength and bone health, future studies focusing on the adjustment of confounding factors are still needed.

The foremost strength of the present study is its investigation of several factors related to bone 
health in combination. Other strengths of the study are the large sample size and the usage of objective measurement methods such as dynamometer, DEXA and blood test.

The first limitation of the study is that we have not been able to measure physical activity level in a more objective manner. Another limitation is the heterogeneous distribution of participants among the subgroups in terms of physical activity level and bone health status.

\section{CONCLUSION}

Conclusively; low body weight, low levels of participation in aerobic activity and low handgrip strength might be risk factors for deterioration of bone health in older adults. Therefore, the elimination or management of these factors may contribute to decrease in osteoporosis risk as well as osteoporosis related secondary conditions such as fractures.

For future studies, we suggest the use of objective measurement methods for assessing physical activity level rather than self-reported questionnaires to extensively investigate the effect of participation in physical activity on bone health. Also, studies focusing on the adjustment of confounding factors in terms of handgrip strength are still needed.

\section{REFERENCES}

1. Demontiero O, Vidal C, Duque G. Aging and bone loss: new insights for the clinician. Ther Adv Musculoskelet Dis. 2012;4(2):61-76. [CrossRef]

2. Plawecki K, Chapman-Novakofski K. Bone health nutrition issues in aging. Nutrients. 2010;2(11):1086-105. [CrossRef]

3. Goh VH, Hart WG. Aging, lifestyle factors, hormones and bone health in Singaporean men. Bone Rep. 2016;5:110116. [CrossRef]

4. Pedone C, Napoli N, Pozzilli P, et al. Bone health as a function of adipokines and vitamin $\mathrm{D}$ pattern in elderly patients. Rejuvenation Res. 2013;16(6):467-74. [CrossRef]

5. Rodríguez-Gómez I, Mañas A, Losa-Reyna J, et al. The Impact of Movement Behaviors on Bone Health in Elderly with Adequate Nutritional Status: Compositional Data Analysis Depending on the Frailty Status. Nutrients.
2019;11(3). pii: E582. [CrossRef]

6. Gatt I, Smith-Moore S, Steggles C, Loosemore M. The Takei Handheld Dynamometer: An Effective Clinical Outcome Measure Tool for Hand and Wrist Function in Boxing. Hand (N Y). 2018;13(3):319-324. [CrossRef]

7. Lyons JG, Heeren T, Stuver SO, Fredman L. Assessing the agreement between 3-meter and 6-meter walk tests in 136 community-dwelling older adults. J Aging Health. 2015;27(4):594-605. [CrossRef]

8. Topolski TD, LoGerfo J, Patrick DL, Williams B, Walwick J, Patrick MB. The Rapid Assessment of Physical Activity (RAPA) among older adults. Prev Chronic Dis. 2006;3(4):A118.

9. Kanis JA (on the behalf of World Health Organisation Scientific Group). Assessment of osteoporosis at the primary health-care level. Technical Report. World Health Organization Collaborating Centre for Metabolic Bone Diseases, University of Sheffield, UK. 2007: Printed by the University of Sheffield. Available from: https://www. sheffield.ac.uk/FRAX/pdfs/WHO_Technical_Report.pdf

10. Gunn CA, Weber JL, Kruger MC. Diet, weight, cytokines and bone health in postmenopausal women. J Nutr Health Aging. 2014;18(5):479-86. [CrossRef]

11. Reid IR. Fat and bone. Arch Biochem Biophys. 2010 Nov $1 ; 503(1): 20-7$. [CrossRef]

12. Kawai M, de Paula FJ, Rosen CJ. New insights into osteoporosis: the bone-fat connection. J Intern Med. 2012 Oct;272(4):317-29. [CrossRef]

13. Pham TT, Nguyen DN, Dutkiewicz E, Center JR, Eisman JA, Nguyen TV. A profiling analysis of contributions of cigarette smoking, dietary calcium intakes, and physical activity to fragility fracture in the elderly. Sci Rep. 2018;8(1):10374. [CrossRef]

14. Rodríguez-Gómez I, Mañas A, Losa-Reyna J, et al. The Impact of Movement Behaviors on Bone Health in Elderly with Adequate Nutritional Status: Compositional Data Analysis Depending on the Frailty Status. Nutrients. 2019;11(3). pii: E582. [CrossRef]

15. Nilsson M, Sundh D, Mellström D, Lorentzon M. Current Physical Activity Is Independently Associated With Cortical Bone Size and Bone Strength in Elderly Swedish Women. J Bone Miner Res. 2017;32(3):473-485. [CrossRef]

16. Qu X, Zhang X, Zhai Z, et al. Association between physical activity and risk of fracture. J Bone Miner Res. 2014;29(1):202-11. [CrossRef]

17. Langsetmo L, Hitchcock CL, Kingwell EJ, et al. Physical activity, body mass index and bone mineral density-associations in a prospective population-based cohort of women and men: the Canadian Multicentre Osteoporosis Study (CaMos). Bone. 2012;50(1):401-8. [CrossRef]

18. Rianon NJ, Lang TF, Sigurdsson G, et al. Lifelong physical activity in maintaining bone strength in older men and women of the Age, Gene/Environment SusceptibilityReykjavik Study. Osteoporos Int. 2012;23(9):2303-12. [CrossRef]

19. Vuillemin A, Guillemin F, Jouanny P, Denis G, Jeandel C. Differential influence of physical activity on lumbar spine and femoral neck bone mineral density in the elderly population. J Gerontol A Biol Sci Med Sci. 2001;56(6):B24853. [CrossRef]

20. Schöffl I, Kemmler W, Kladny B, Vonstengel S, Kalender WA, Engelke K. In healthy elderly postmenopausal women variations in BMD and BMC at various skeletal sites are associated with differences in weight and lean 
body mass rather than by variations in habitual physical activity, strength or VO2max. J Musculoskelet Neuronal Interact. 2008;8(4):363-74.

21. Foley KT, Owings TM, Pavol MJ, Grabiner MD. Maximum grip strength is not related to bone mineral density of the proximal femur in older adults. Calcif Tissue Int. 1999 Apr;64(4):291-4. [CrossRef]

22. Marin RV, Pedrosa MAC, Moreira-Pfrimer LDF, Matsudo SMM, Lazaretti-Castro M. Association between lean mass and handgrip strength with bone mineral density in physically active postmenopausal women. J Clin Densitom. 2010;13(1):96-101. [CrossRef]

23. Santilli V, Bernetti A, Mangone M, Paoloni M. Clinical definition of sarcopenia. Clin Cases Miner Bone Metab. 2014;11(3):177-80. [CrossRef]

24. Chainani V, Shaharyar S, Dave K, et al. Objective measures of the frailty syndrome (hand grip strength and gait speed) and cardiovascular mortality: A systematic review. Int J Cardiol. 2016;215:487-93. [CrossRef] 